\title{
First report of Moroccan watermelon mosaic virus on edible seed squash in Turkey
}

\author{
Serkan Yeşil ${ }^{1}$ (D) \\ Received: 13 January 2021 / Accepted: 9 March 2021 / Published online: 22 March 2021 \\ (c) Società Italiana di Patologia Vegetale (S.I.Pa.V.) 2021
}

Keywords DAS-ELISA $\cdot$ Edible seed squash $\cdot$ MWMV $\cdot$ Potyvirus $\cdot$ RT-PCR $\cdot$ Snack

Squash (Cucurbita pepo L.) is grown for fresh consumption and its seeds are used as a snack in Turkey like in some Mediterranean and European countries, and China. Recently, virus diseases have become one of the most common and devastating problems in cultivation of edible seed squash (C. pepo L.) in Turkey. Since, Moroccan watermelon mosaic virus (MWMV, Genus: Potyvirus) has already been reported several countries in the Mediterranean basin (Bananej et al. 2018), the possibility of transmission of the virus was very high by imported plant material to Turkey. Therefore, a survey was carried out during August 2019, a total of 45 leaf samples showing virus-like symptoms were randomly collected from 12 squash fields in Aksaray province in the Central Anatolian Region of Turkey. For determination of MWMV infections, the samples were tested by DAS-ELISA according to manufacturer's instructions (SEDIAG, France). According to the results of DAS-ELISA, six MWMVinfected samples (13.33\%) were determined. To confirm the DAS-ELISA results, total RNA extractions were obtained by using silica-gel based method (Foissac et al. 2005) and RTPCR tests were performed using specific primers MWMV5'/MWMV-3' (5'-AGCAAGCGCCATACTCTGA-3' and: 5'-CAAACTCCA TTAACATTCGG-3'), to amplify partial sequence of polymerase $(\mathrm{NIb})$ and coat protein $(\mathrm{CP})$ genes, about 627 bp (Lecoq et al. 2007). RT-PCR results confirmed DAS-ELISA results of the six MWMV-positive samples. The MWMV-infected plants showed mild to severe mosaic, blistering, and mottling on the leaves. One of the randomly selected positive PCR products was sent for sequencing (REFGEN Biotechnology, Turkey). The raw sequence was manually refined and obtained trimmed sequence

Serkan Yeşil

serkanyesil@ selcuk.edu.tr

1 Department of Plant Protection, Faculty of Agriculture, Selçuk University, Konya 42075, Turkey
(589 bp) was analyzed by CLC Genomics Workbench v.7.5 software (QIAGEN, Denmark). Then it was submitted to GenBank (Accession No. MW362132), which revealed 99.15\% sequence identity with two MWMV Greek isolates (LN810061 and KF772944) by BlastN analysis. This is the first report of MWMV in Turkey.

Funding This research was supported by the Selçuk University Scientific Research Projects Coordinator (Project number 18401150).

Data availability The datasets generated during and/or analyzed during to current study are available from the corresponding author on reasonable request.

\section{Declarations}

Conflict of interest There is no conflict of interest.

\section{References}

Bananej K, Orfanidou CG, Maliogka VI, Katis NI (2018) First Report of Moroccan Watermelon Mosaic Virus in Zucchini in Iran. Plant Dis 102:10. https://doi.org/10.1094/PDIS-03-18-0389-PDN

Foissac X, Svanella-Dumas L, Gentit P, Dulucq MJ, Marais A, Candresse T (2005) Polyvalent degenerate oligonucleotides reverse transcription-polymerase chain reaction: a polyvalent detection and characterization tool for Trichoviruses, Capilloviruses, and Foveaviruses. Phytopathology 95:617-625. https://doi.org/10.1094/ PHYTO-95-0617

Lecoq H, Justafré I, Wipf-Scheibel C, Desbiez C (2007) Moroccan watermelon mosaic virus newly reported on zucchini squash in France. New Dis Rep 16:19

Publisher's Note Springer Nature remains neutral with regard to jurisdictional claims in published maps and institutional affiliations. 